\title{
DYNAMICS OF HAJJ FINANCIAL MANAGEMENT REGULATION IN EFFORTS TO GOOD GOVERNANCE
}

\author{
Muhammad Aziz Zakiruddin \\ Faculty of Sharia and Law, UIN Fatmawati Sukarno Bengkulu \\ Jl. Raden Fatah, Pagar Dewa, Bengkulu \\ Email: Aziz.zakiruddin@iainbengkulu.ac.id
}

\begin{abstract}
Hajj financial management, especially within the scope of the Ummah Endowment Fund, has a dark record that must be corrected. Not only limited to investment, but the discourse of Hajj funds for infrastructure is also one of the government's efforts so that Hajj funds can provide use-value. Legal certainty, justice, equality, prohibition of acting arbitrarily, and creating welfare and social cohesiveness in society are the principles of good governance. In Indonesia, to establish an orderly organization of Hajj, laws and regulations, government regulations, presidential regulations, and regulations for the Hajj Financial Management Agency have been made. As for the formulation of the problem in this paper, how are the dynamics of the financial management of Indonesian Hajj?, and how are the efforts to manage the Hajj finances based on good governance?. This research is library research, using a normative juridical method with a statutory approach. Some of the findings in this study indicate that regulations in the financial management of Hajj provide a polemic of its own so that it loses its identity and principle. Dualism of authority, inefficient management, and the potential for fraud are demands to fix the messy financial management of Hajj, towards good governance-based Hajj financial management.
\end{abstract}

Keywords: Hajj Financial Management; Good Governance; Hajj Regulation

\begin{abstract}
Abstrak: Pengelolaan keuangan haji, khususnya dalam lingkup Dana Wakaf Ummah, memiliki catatan kelam yang harus diperbaiki. Tidak hanya sebatas investasi, wacana dana haji untuk infrastruktur juga menjadi salah satu upaya pemerintah agar dana haji dapat memberikan nilai guna. Kepastian hukum, keadilan, kesetaraan, larangan bertindak sewenang-wenang, serta menciptakan kesejahteraan dan kerukunan sosial dalam masyarakat merupakan prinsip-prinsip pemerintahan yang baik. Di Indonesia, untuk membangun tertib penyelenggaraan haji, dibuat peraturan perundang-undangan, peraturan pemerintah, peraturan presiden, dan peraturan Badan Pengelola Keuangan Haji. Adapun masalah dalam tulisan ini, bagaimana dinamika pengelolaan keuangan haji Indonesia?, dan bagaimana upaya pengelolaan keuangan haji berbasis good governance?. Penelitian ini merupakan penelitian kepustakaan, menggunakan metode yuridis normatif dengan pendekatan perundangundangan. Beberapa temuan dalam penelitian ini menunjukkan bahwa regulasi dalam pengelolaan keuangan haji memberikan polemik tersendiri sehingga kehilangan identitas dan asasnya. Dualisme kewenangan, pengelolaan yang tidak efisien, dan potensi kecurangan menjadi tuntutan untuk membenahi tata kelola keuangan haji yang berantakan, menuju pengelolaan keuangan haji berbasis good governance.
\end{abstract}

Kata kunci: Manjemen Keuangan Haji; Pemerintahan yang Baik; Peraturan Haji 


\section{Introduction}

Discussing the pilgrimage is not always in the context of the implementation of series of rituals carried out in the pilgrimage; the problems that arise in the pilgrimage in the modern era today are not limited to discussions in the context of figh, the pillars and conditions of the pilgrimage, the meaning and spiritual values of worship. Hajj, but in reality, the problematic financial management of Hajj provides more complex problems, especially in Indonesia.

The length of the hajj queues, the problem of hajj quotas, the hajj bailouts that are becoming a trend in the community, and the prospective congregational registration system, which is considered to be still reaping many problems, ${ }^{1}$ are some of the issues that arise in the implementation of the pilgrimage in Indonesia. The financial management of the Hajj was not spared from various points; the Ministry of Religion, which later became the regulator, operator, and supervisor at the same time in organizing the Hajj, became a weakness in the financial management of the Hajj. ${ }^{2}$ The breadth of authority and power of the Ministry of Religion in the direction of Hajj finances opened up opportunities for power holders within the Ministry of Religion to politicize the control of Hajj finances; this later became the focus of economists and legal experts, concerns that arose in the community finally occurred, political banality and authority were shown by those who hold the highest power in the Ministry of Religion, Said Agil Husain Al-Munawar and Suryadharma Ali,

${ }^{1}$ Zubaedi, "Analisis Problematik Manajemen Pelaksanaan Haji di Indonesia," Jurnal Manhaj I, Fakultas Tarbiyah dan TadrisIAIN Bengkulu, Vol. 4, No 3, September 2016, p. 190.

${ }^{2}$ Komisi VIII DPR RI, "Naskah Akademis Rancangan Undang-Undang tentang Penyelenggaraan Ibadah Haji danUmrah, (April 2016), p. 6. are a dark record in the financial management of Hajj.

Law No. 34 of 2014 concerning Hajj Financial Management has become a breath of fresh air in the management of Hajj finances; the Law mandates the establishment of the Hajj Financial Management Agency (BPKH) as an independent agency directly responsible to the President.

It is recorded that 103 trillion rupiahs of hajj funds are ready to be managed at the beginning of the formation of the $\mathrm{BPKH}$ and worth 3.2 trillion, of which is the value of benefits or what is called the People's Endowment Fund (DAU). ${ }^{3}$ DAU is several funds that result from the development of the DAU and or the remaining operational costs for the implementation of the pilgrimage and are the result of other sources that are not binding following statutory provisions. ${ }^{4}$

Article 47 of Law No. 13 of 2008 concerning the implementation of the pilgrimage mandates the management of the DAU to provide use values and benefits for the benefit of Muslims, which can be used in Hajj services, education and da'wah, health, socio-religious, economic, and development services. Worship facilities and infrastructure.

Pilgrims hajj funds managed by $\mathrm{BPKH}$ are not necessarily allowed to settle, based on Law No. 34 of 2014 in article 10, so that the collected hajj funds continue to move and can provide benefits, especially for the pilgrims, the hajj funds are invested in various sectors, such as State Sharia Securities (SBSN) or

3 "Dana Haji Indonesia mencapai Rp 105 trilliun," https://bandung.kompas.com/read/2018/05/21/13033161/ dana-haji-di-A-capai-rp-105-triliun. Accessed on 9 October 2019.

${ }^{4}$ Law No. 34 of 2014 concerning The Management of Hajj Finance. 
Sukuk, and invested in several Islamic banks, ${ }^{5}$ $5 \%$ of which is invested in gold, then $25 \%$ direct investment in 2018 and it is estimated that direct investment will increase by $20 \%$ in 2020. Placements in Islamic Commercial Banks or Sharia Business Units in 2018 are expected to be reduced by $50 \%$ so that only $30 \%$ is placed in B.U.S. or U.U.S.; this is done to boost investment in Hajj funds Sukuk as well as direct investment and other investments. ${ }^{6}$

The mandate for investing in Hajj funds has been around for a long time, and this is also stated in Article 57 of Law No. 13 of 2008. However, it turns out that the discourse on investing in Hajj funds had become public anxiety when President Jokowi expressed his desire to invest Hajj funds in the infrastructure sector. And this is also supported by the Minister of Religion and the Chairman of the $\mathrm{BPKH}^{7}$

Hajj funds have great potential with various schemes, one of which is through Sukuk to enter the infrastructure sector, with the potential for Hajj funds to at least reduce the promising trend of Indonesia's foreign debt. ${ }^{8}$

The pilgrimage illustrates that the pilgrimage is only in the category of qashirah worship (individual worship), whose benefits can only be felt by the doer.However, the concept of financial management of Hajj, which has the value of use in economic development, illustrates that the pilgrimage is not only

5 EndangJumali, "Management Of Hajj Funds In Indonesia," Journal of Legal, Sultan Zainal Abidin University, Vol. 21, No, 3, Malaysia 2018, p. 6.

${ }^{6}$ Badan Pengelolahan Keuangan Haji, "Pengelolahan Dana Haji danRencanaStrategis BPKH 2018-2022” http://BPKH.co.id, Jakarta (December 2017).

7 "Jokowi Ingin Dana Haji diinvestasikan Untuk Infrastruktur," https://nasional.kompas.com/read/2017/07/ 26/12145401/jokowi-ingin-dana-haji-diinvestasikan-untukinfrastruktur?page=all. Accessed on 9 October 2019.

${ }^{8}$ Ibid..,p. 4. in the category of individual worship but has arrived at the category of muta'addiyah worship (social worship), where many people will feel the benefits.

The aspiration to develop Indonesia's economyby optimizing hajj funds is not easy. It requires further and in-depth study, but basically, hajj funds are quite sensitive financial shutters because they collide with religious issues. Therefore the financial management of Hajj must support by appropriate regulations; this regulation is not only based on religious doctrines but must also be supported by various other aspects that aim at development on a national scale, and are fair and uphold the hopes and interests of the people, in this case, the claims of the hajj pilgrims.

Efforts to build Hajj financial management and utilization need to be made through the principles of good governance. Good governance itself is often interpreted as an ideal form of government; good governance focuses on the growth of the public sector, which also synergizes to manage resources to be more effective and efficient for the benefit of the community and can be accounted for and in line with the Law. So that the formation of regulations in encouraging efforts to utilize Hajj finance more effectively and efficiently, as well as providing benefits for the congregation in particular, and for the economy and the use of the people in general, needs to be pursued based on good governance.

Through the explanation above, the focus of this research is: First, how are the dynamics of the regulation of Hajj financial management? Second, how is the Hajj financial regulation based on Good Governance? 


\section{Research Method}

This research is a Library Research study, using a normative juridical approach, namely by reviewing and digging further into the laws and other regulations governing the regulation of Hajj financial management, which are then studied or viewed from the point of view of the theories used. The hajj Financial Management Act, P.K.H. Academic Manuscripts, and the historicization of the Hajj pilgrimage become the primary data in this study. The historical implementation of the pilgrimage is used to reveal how the dynamics of regulation occur in the financial management of the pilgrimage. Through the dynamics that occur and the applicable laws are reviewed and reviewed from the point of view of Good Governance.

\section{Dynamics of Hajj in Indonesia}

The Dutch government officially issued regulations regarding hajj trips in 1859 , namely the pilgrimsordonantie. This regulation is the first Hajj regulation published in the Staatblad van Nederlandsch-Indie and translated into two languages, namely Malay and Chinese.' This ordinance contains the Hajj pass, financial requirements, administrative requirements for Hajj, and fines. ${ }^{10}$ The Dutch policy regarding

${ }^{9}$ M. Dien Majid, Berhaji di MasaKolonial (Jakarta: CV Sejahtera, 2008), p. 95 Steps in improving the colonial period in 1921 the efforts made by the Muslim movement pioneered by K.H. Ahmad Dahlan demanded that the Three Cooperatives improve services for the Hajj pilgrimage in Indonesia. In 1922 the Dutch East Indies government regulated matters relating to the implementation of the pilgrimage, especially regarding security, transportation and facilities during the journey. see: AchmadNidjamdan A. LatiefHannan, Manajemen Haji (Jakarta: Zikrul Hakim, 2001), Cet. VI, p. 23

${ }^{10}$ See Staatblad van Nederlandsch-Indie 6 July 1859 No. 42. There is something interesting about art. 3 of this ordinance, which explains the obligation of pilgrims to ask for visas for those who have a hajj pass to the Dutch the Hajj Ordinance underwent several changes and improvements, recording twenty-two changes from 1867 to $1937 .{ }^{11}$

At the beginning of independence in 1948, the Indonesian government sent a hajj mission, which consisted of several people, among others, K.R.H. Moh Adnan, H. Ismail Banda, H. Saleh Suady, and H. SamsirSutanAmeh, the missionaries were sent to Mecca to face the King of Saudi Arabia, which is a form of a government effort to encourage better Hajj and Umrah services. ${ }^{12}$ Seeing the movement carried out by the Indonesian government, the Netherlands also did not want to be left behind by sending an honorary mission from the State of East Indonesia (one of the puppet states created by the Dutch after 1945). This honorary mission intends to visit the King of Saudi Arabia and foster a spirit of good faith among Muslims. The government of Saudi Arabia as the host is neutral by accepting representatives from the State of East Indonesia and representatives from the Republic of Indonesia. ${ }^{13}$

The implementation of the Hajj at the beginning of independence was carried out by the Indonesian Hajj Organizer $(\mathrm{PHI}){ }^{14}$ residing

Consulate, even though at that time there was no Dutch consulate in Jeddah. The Dutch just established a Dutch consulate in Jeddah in 1872 .

${ }^{11}$ Changes to the Hajj Ordinance occurred in 1867 , $1872,1875,1881,1898,1901,1902,1904,1905,1906$, 1909, 1911, 1912, 1913, 1914, 1915, 1920, 1922, 1923, 1927, 1932, 1937. See: Ahmad Fauzan, "Sailing for Hajj Pilgrims in the Dutch East Indies 1911-1930)" Al-Turas, Vol. XXII, No. 1, January 2016, p. 4

${ }^{12}$ Ahmad Subianto, Menata Kembali Manajemen Haji Indonesia (Jakarta: Yakamus dan Gibon Books, 2016), Cet ke-1, p. 9. see: Sumuran Harahap dan Mursidi Mr, Lintasan Sejarah Perjalanan Jemaah Haji Indonesia (Jakarta: Insan Cemerlang, TT), p. 58-59

${ }^{13}$ Jacob Vredenbregt, "The Haddj: Some of its Features and Function in Indonesia, Brijdragen tot de taal, Brill, 1962, p. 110 .

14 The Hajj Organizer (PHI) was established on January 21, 1950. The Hajj at that time was carried out 
in each residency or regional government. In further developments, the Indonesian Muslim Congress Agency (BKMI) established a foundation that explicitly handles the pilgrimage, namely the Indonesian Hajj Travel Improvement Committee (PPHI) chaired by K.H.M. Sudjak. PPHI's position was strengthened when the Minister of Religion issued the Letter of the Ministry of Religion R.I.S. No. 3170 of 1950 and the Circular Letter of the Minister of Religion R.I.S. No. A. III/I/648 of 1950 appointed PPHI as a legal institution besides the government to manage and organize the pilgrimage in Indonesia. At that time, one of the essential steps in improving the implementation of the Hajj and Umrah pilgrimages by the government, in this case, the Ministry of Religion, was the transfer of sea transportation to more modern air transportation to reduce the suffering of pilgrims when boarding ships that were full of dangers. During the 1950s, the Hajj and Umrah committees were not carried out directly by the Ministry of Religion. Almost every year, Muslims' interest in performing the pilgrimage has never subsided; even the rate of development shows an increasing graph even though the costs set by the government always show a significant increase every year. ${ }^{15}$

The PHI's cooperation with the Ministry of Religion in organizing the first Hajj in several ways still raises suspicions and misunderstandings from several regional agencies. Therefore, on February 8, 1951, a Joint Declaration was issued between the Ministry of Religion and the I.R.C. This edict contains the obligations of the Indonesian

by the PHI who was in each residency (local government) see: Achmad Nizam dan Alatief Hanan, Manajemen Haji: Studi Kasusdan Telaah Implementasi Knowledge Worker (Jakarta: Zikrul Hakim, 2003), p. 26.

15 Achmad Nizam dan Alatief Hanan, Manajemen Haji..., p.12
Ministry of Religion, the obligations of the PHI, and the cooperation between the Indonesian Ministry of Religion and the PHI. This edict also clearly states the boundaries between the PHI and the Ministry of Religion in organizing hajj affairs. ${ }^{16}$

In 1952 P.T. Indonesian Muslim Shipping (MUSI). The establishment of P.T. MUSI on the initiative of the PHI, which received approval from the Minister of Religion. P.T. MUSI is the only company that serves as the Hajj committee in transporting prospective pilgrims. ${ }^{17}$ In the same year, Bank Haji Indonesia (B.H.I.) was also established. B.H.I. is in charge of organizing and managing Hajj finances. Several local private banks are also allowed to accept deposit and remittance of O.N.H. deposits, such as the Sulawesi Development Bank, Banjarmasin Indonesia Dagang Bank, and Medan National Dagang Bank. ${ }^{18}$

In 1962 or ten years after its establishment, the government frozen the PHI. ${ }^{19}$ In 1962 ,

16 Sumuran Harahap dan Mursidi Mr, Lintasan Sejarah Perjalanan ..p. 73-75

17 Achmad Nizam dan Alatief Hanan, Manajemen Haji: StudiKasus..., p. 27

18 Sumuran Harahap dan Mursidi Mr, Lintasan Sejarah. p. 11-115

${ }^{19}$ The PHI was suspended by the government due to political considerations because many of the PHI figures were members of Masjumi. Since September 1960 Masjumi was disbanded while its leaders were in prison. See: Ira M. Lapindus, Sejarah Sosial Ummat Islam, Terj Ghufron A Mas'adi (Jakarta: PT Raja Grafindo Persada, 2000), 343. Prior to its disbandment, the change in the government system from parliamentary to presidential had an impact on the PHI, starting with President Soekarno's initiative to try to reform the organization of the Hajj. Since 1950, the PHI has been seen as a semi-government institution as well as a part of the Ministry of Religion. However, since the issuance of the Decree of the Minister of Youth for Religion No. 36 of 1959, concerning the position and withdrawal of the recognition of the PHI as an institution working under the protection of the Ministry of Religion, and indirectly the PHI no longer receives direct orders from the Government. see: MochNurIchwan, "Governing 
P.T. MUSI and Bank Haji Indonesia (B.H.I.) were also dissolved. Dissolution of P.T. MUSI and B.H.I. are closely related to the suspension of PHI by the government. ${ }^{20}$ In 1962, the government formed the Hajj Travel Improvement Committee (P3H) with Muljadi Djojomartono (Coordinating Minister for People's Welfare) as its chairman. The government gave $\mathrm{P} 3 \mathrm{H}$ two essential tasks. First, the short-term task, namely $\mathrm{P} 3 \mathrm{H}$, must formulate guidelines and main functions of each government and private agency directly involved in organizing Hajj. Second, the longterm job is that $\mathrm{P} 3 \mathrm{H}$ must revise (change) the 1919 Ordinance and the Dutch government regulations related to the implementation of Hajj, which is not following the 1945 Constitution. $^{21}$

In 1964, P3H was dissolved and replaced by the Hajj Affairs Council (DUHA) ${ }^{22}$, with the chairman remains MuljadiDjojomartono (Coordinating Minister for People's Welfare). During this DUHA period, the ideals of Muslims to have their pilgrimage ship began to be realized. With the issuance of Presidential Decree No. 122 of 1964 concerning efforts to purchase vessels and extraordinary means of transportation to transport Indonesian pilgrims. So in that year, P.T. Arafat was engaged in shipping and was given the same authority as P.T. MUSI in 1952-1962. ${ }^{23}$

The Reformation Era became a new beginning in implementing the pilgrimage in

Hajj: Politics of Islamic Pilgrimage Services in Indonesia Prior to Reformasi Era”, Al-Jamiah, Vol. 46, No. 1, (2008), p. 130.

${ }^{20}$ Deliar Noer, Administrasi Islam di Indonesia (Jakarta: CV Rajawali, 1983), p. 106

${ }^{21}$ Moch NurIchwan, "Governing Hajj..p. 131.

${ }^{22}$ Muhammad Nuri, "Pragmatisme Penyelenggaraan Ibadah Haji di Indonesia," Jurnal Sosial dan Budaya Syar-I UIN Jakarta, Vol. 1, No.1, Juni 2014, p. 151.

23 Sumuran Harahap dan Mursidi Mr, Lintasan Sejarah Perjalanan..p. 130-131
Indonesia, with Law no. 17 of 1999 concerning the Organization of the Hajj. This Law is expected to be a new chapter in implementing a higher-quality pilgrimage. The formation and ratification of Law No. 17 of 1999 is an effort to improve the system and management of the implementation of the pilgrimage that needs to be continuously improved so that the performance of the pilgrimage runs safely, orderly, and smoothly following religious demands. ${ }^{24}$ In Article 1 of the general provisions, it is stated that the activities that are the scope of the implementation of the pilgrimage are: fostering, serving, and protecting the performance of the pilgrimage. Even so, the government's efforts to build good Hajj management are still receiving criticism. The Ministry of Religion is considered to have a monopoly on the implementation of the Hajj. The Ministry of Religion stands in a very central position, where the functions as a regulator, operator, and evaluator rest on the authority of the Ministry of Religion. The accumulation of power results in overlapping policies and creates many shortcomings in the organization of the pilgrimage.

The centralization of the implementation of the Hajj at the Ministry of Religion continued until the enactment of Law No. 13 of 2008, which was an amendment to Law No. 17 of 1999 concerning the Implementation of the Hajj. Law No. 13 of 2008 provides a new face for the organization of the pilgrimage that is more professional. Law No. 13 of 2008 provides unique and essential aspects in organizing the expedition and a more transparent organization. Law No. 13 of 2008 gives a signal to be a step more innovative. However, the centralization of authority within the Ministry of Religion

${ }^{24}$ Law No. 17 of 1999 concerning the Organization of the Hajj 
is still a particular concern, as stated in Article 10 paragraph 1 of Law No. 13 of 2008, which says that the government, in this case, the Ministry of Religion, is still the organizer of worship. Hajj is obliged to manage and carry out the implementation of the pilgrimage. ${ }^{25}$

The issuance of Law No. 34 of 2014 concerning Hajj Financial Management and Law No. 8 of 2019 amendments to Law No. 13 of 2008 concerning the Organization of the Hajj. This shows the government's efforts to improve Hajj and Hajj financial management by limiting the authority of the Ministry of Religion which was previously so central. Law No. 34 provides for establishing a particular agency that is independent and directly responsible to the President in the management of Hajj finances, known as the Hajj Financial Management Agency (BPKH).

\section{Good Governance}

Good governance may not be too difficult to define, and we can call it good governance; in general, the word good governance provides various definitions, but the term governance is not the same as government, as stated by Ganie Rochman that the concept of "government" refers to an organization. Management is based on the highest authority, namely the State and Government. Meanwhile, the idea of "governance" involves the Government and the State and the roles of various actors outside the Government and the State so that the parties involved are comprehensive. ${ }^{26}$

United Nations Development Program (UNDP) provides a definition: that good

${ }^{25}$ Law No. 13 of 2008 concerning the Organization of the Hajj.

${ }^{26}$ Joko Widodo, Good Governance: Telaah dari Dimensi Akuntabilitas Kontrol Birokrasi Pada Era Desentralis dan Otonomi Daerah (Surabaya: InsanCendikia, 2001), p. 18. governance is the use or implementation of politics, economics, and administration to manage national problems at all levels; UNDP highlights good governance through legitimate authority or power that has legitimacy, this definition from UNDP seems to emphasize more that the role in good management can be seen from the use of control and energy which can be an instrument in the formation of policies that can encourage the creation of conditions of welfare, integrity, and social cohesiveness in society. ${ }^{27}$

The World Bank defines governance as a way of state power to regulate its economic resources and social resources for community development. Ganie Rochman also describes governance as a mechanism for managing financial and social resources that involve the State and non-government sectors in a collective activity. ${ }^{28}$

In terms of indicators and characteristics of good governance must meet certain principles, GH Addink said that good governance must be based on the principle of prohibition of acting arbitrarily, the focus of justice or the principle of fairness, the principle of legal certainty, the principle of trust, the principle of equality, the principle of proportionality or the principle of balance, the focus of prudence and the direction of consideration. ${ }^{29}$

Indonesia is a democratic country, are words that we often hear; democracy itself is a government based on the people's interests, placing the people as the epistemological basis of power. From the people, by the people, and for the people, we are familiar with this

27 Sahya Anggara, Ilmu Administrasi Negara Kajian Konsep, Teori dan Fakta dalam Upaya menciptakan Good Governance, (Bandung: CV PustakaSetia, 2012), p. 202.

${ }^{28}$ Hendra Karianga, Politik Hukum dalam Pengelolahan Keuangan Daerah, (Jakarta: Kencana, 2013), p. 188.

${ }^{29}$ Hendra Karianga, Politik Hukum..., p. 193 
terminology in describing democracy and giving sound reasoning, namely by placing the people in three spectrums simultaneously and all of them relying on the people. ${ }^{30}$

The ideal of good governance does not seem like a dream for the Rule of Law. Legal certainty, the loss of arbitrariness, justice, fairness, efficiency, community economic development, principles that are considered relatively easy to live in a democratic country. Not only echoed, Indonesia's system and form of government is a democratic country, but in fact, Indonesia is still in the spotlight seen from the perspective of explaining the current lousy government. Legal certainty, laws that point up and blunt down to the banality of power carried out by those in power, shows how messy democracy is taking place in this beloved country.

\section{Good Governance Targets in Hajj Financial Management}

a. Transparent and Development-Based in Hajj Financial Management

The Hajj Organizing Fee (BPIH) is a sum that the Hajj pilgrims must deposit to the government; the government will use the BPIHto finance the Hajj implementation. Indonesia, a Muslim-majority country, has extraordinary enthusiasm in fulfilling the fifth pillar of Islam. However, with limited quotas, every year, causing queues or what we often call a waiting list, this limited number of allocations causes prospective pilgrims who have deposited BPIH cannot be dispatched directly, so BPIH funds cannot be used now, the collected BPIH will become part of the Hajj Fund fund, which the government will then manage.

30 Sarifuddin Sudding, Perselingkuhan Hukum dan Politik dalam Negara Demokrasi (Yogyakarta: Rangkanf Education, 2014), p. 17.
In Article 2 of Law No. 34 of 2014 concerning Hajj Financial Management, Hajj financial management is based on the principles of governance based on sharia principles, prudence, benefits, non-profit, transparent and accountability; Hajj financial management has the aim of improving the quality of Hajj implementation, rationality and efficient use of BPIH, and aims to have value benefits for the benefit of Muslims.

Hajj finances include receipts, expenditures, and wealth, hajj financial receipts sourced from BPIH deposits, the value of benefits, and efficiency funds for implementing the pilgrimage, DAU, and other sources. Hajj financial expenses include costs for organizing the expedition, operational BPKH placements and/or pilgrimage financial investments, refunds for deposits, and activities for the benefit of Muslims.

Article 1 of Law No. 13 of 2008 concerning the Organization of the Hajj defines the People's Endowment Fund, known as the DAU, which is several funds obtained from the results of the development of the DAU itself and or are the remainder of the optimization of operational costs for the Organization of the Hajj and other sources lawful and non-binding. Based on the same Law, it is explained that the DAU is managed by the People's Endowment Fund Management Agency (BPDAU) ${ }^{31}$, before finally, Law No. 34 of 2014 concerning Hajj Financial Management mandated the formation of the Hajj Financial Management Agency $(\mathrm{BPKH})$ then based on the Law the DAU became the responsibility of BPKH.

${ }^{31}$ In Article 47 of Law No. 13 of 2008 concerning the Organization of the Hajj, it contains provisions and the role of BP DAU as an agency that is given responsibility for managing DAU. 
BP DAU and BPKH do not have differences in the mandate of managing the People's Endowment Fund; in Article 47 of Law No. 13 of 2008, that the management of DAU aims to be more efficient for the benefit of Muslims, DAU can be allocated in the activities of pilgrimage services, da'wah, health, socio-religious, economic, and construction of religious facilities and infrastructure. However, the role of $\mathrm{BPKH}$ covers a broader scope, not only managing the DAU but also managing the Hajj Fund as a whole, so that the presence of BPKH makes the Ministry of Religion focus on organizing the pilgrimage.

Investments and benefit programs are a series of $\mathrm{BPKH}$ responsibilities in managing Hajj finances; investments are made so that the Hajj funds do not just settle but so that the Hajj funds provide added value. Hajj fund investment activities are not necessarily an initiative or BPKH's desire to get more deals from Hajj funds without any authority; this has been regulated in the Hajj financial management law that $\mathrm{BPKH}$ has the power to place and invest Hajj finances based on sharia principles, prudence caution, and safety and value benefits.

Hajj fund investment has enormous potential not only for the organization of the pilgrimage but also to help the economy, but this investment in Hajj funds is still much controversy, especially when President Jokowi expressed his desire to use Hajj funds as a source of infrastructure funding. Although the Head of BPKH voiced his support for the plan, with the pros and cons of investing in Hajj funds for infrastructure, the Chairman of BPKH said that not a penny of Hajj funds was used for infrastructure.

Although the investment of Hajj funds in the infrastructure sector raises pros and cons as well as rejection from some circles, ${ }^{32}$ However, basically the investment of Hajj funds for infrastructure has been carried out by Malaysia through an institution called Tabungan Haji Malaysia, Malaysia has used Hajj funds as a source of infrastructure funding, such as in the plantation sector, and other profitable sectors. ${ }^{33}$ From the various benefits generated from the investments made by Tabungan Haji Malaysia, the pilgrims can feel the benefits directly, namely, where Tabungan Haji Malaysia has paid zakat for the pilgrims every year. ${ }^{34}$

B.P.K. as the agency authorized to manage Hajj finances, stated that not a penny of Hajj funds was invested in infrastructure, ${ }^{35}$ Even though BPKH said that, basically investing hajj funds in the infrastructure sector was supported

32 The Indonesian Consumers Foundation (YLKI) stated its rejection of the government's move to invest hajj funds for infrastructure, this was considered a violation of the rules, the issue of the willingness of the pilgrims, as well as investments carried out according to sharia or not being the basis for YLKI to reject the government's plan., see:" YLKI TolakLangkah Pemerintah Investasikan Dana Haji untukInfrastruktur," https://ekonomi.kompas. $\mathrm{com} / \mathrm{read} / 2017 / 07 / 28 / 153002126 /$ ylki-tolak-langkahpemerintah-investasikan-dana-haji-ke-infrastruktur-. Accessed on 9 October 2019. Not only YLKI, this problem has also drawn criticism from the deputy chairman of the DPR, Fahri Hamzah, Fahri Hamzah has criticized this, according to him, there are still many things that need to be prioritized to be addressed.see: "Pro Kontra Dana Haji Untuk PembiayaanInfrastruktur," https://beritagar. $\mathrm{id} /$ artikel/berita/pro-kontra-dana-haji-untuk-pembiayaaninfrastruktur. Accessed on 9 October 2019.

${ }^{33}$ Bayu Taufiq Possumah, "Hajj Fund for Infrastructure Development: a Dilemma for Indonesian Muslim," Islamic Finance news, Univestiti Malaysia Terengganu, Malaysia 16 Agustus 2017, p. 20.

34 Riko Nazri, "Bank Haji Indonesia: Optimalisasi Pengelolaan Dana Haji Untuk Kesejahteraan Jemaah Haji Indonesia (Sebuah gagasan)," Jurnal Khazanah I, FIAI Univesitas Islam Indonesia, Vol. 6, No. 1. Juni 2013, p. 17.

35 "BPKH: Tidak sepeserpun dana haji untuk infrastruktur," https://ekonomi.kompas.com/read/2019/01/ 24/142008126/bpkh-tidak-ada-satu-rupiah-dana-hajiuntuk-infrastruktur. Accessed on 9 October 2019. 
by regulations for managing the hajj finances because investment in the infrastructure sector could fall into the categories of direct and indirect investment or through Sukuk. The development of infrastructure can advance the economy, such as building and accelerating electricity, roads, and clean water infrastructure, which positively influences the economy in Indonesia. However, the availability of financial instruments in Indonesia for infrastructure at the local level is minimal; the low level of these instruments also affects the level of infrastructure in Indonesia. ${ }^{36}$

In planning the 2017-2022 BPKH in the placement of Hajj fund investments, having a scheme to increase investment in the Sukukscheme, direct and indirect assets, and reducing the number of stations in Sharia Business Entities and Sharia Business Units, SUKUK became a placement scheme with the most significant percentage increase of $15 \%$, so that by 2020 placements in the Sukuk scheme will reach 35\%.

Law No. 19 of 2008 concerning State Sharia Securities, SBSN, or State Sukukin its issuance aims to finance the APBN deficit and finance government-owned infrastructure projects. State Sukuk has played an essential role since the distribution of Government Regulation Number 56 of 2011 concerning Project Financing through the issuance of SBSN,${ }^{37}$ which the government has developed project financing through State Sukuk. This is implemented by issuing State Sukukbased on project financing or known as State Sukuk with the PBS series, namely Project-Based

36 Muhammad Asfiroyan, "Optimalisasi Dana Haji Pembangunan Sektor Riil Melalui Skema Project Based sukuk," Politeknik Keuangan Negara, STAN, p. 2.

37 The purpose of issuing SBSN/Sukuk is set out in Article 4 of Law No. 19 of 2008 concerning National Sharia Securities.
Sukuk since 2012. ${ }^{38}$ Therefore indirectly, the placement of Hajj finance through SBSN or Sukukhas penetrated the infrastructure realm. Not only Sukuk, direct or indirect investment can be an option for placing Hajj finance into the infrastructure realm.

Transparency is still a big question in the management of Hajj finances; transparency is a matter of financial statements presented in the public sphere and transparency in cases of government steps in placing Hajj finances. Regulations serve as an umbrella for $\mathrm{BPKH}$ in its stages to widen the realm of investment in Hajj funds. BPKH's movement in looking at the future of hajj funds is seen from the design of the placement of hajj funds, so if BPKH says that not a penny of hajj funds is invested in infrastructure, it's not in sync with the steps that have been implemented.

\section{b. Legal Certainty, Efficiency, and Sustainability in Hajj Financial Management}

The benefits program is one of the $\mathrm{BPKH}$ programs, which is to realize one of the goals in the financial management of the Hajj, which is to provide benefits for the benefit of Muslims. The benefits program is a mandate contained in Law No. 34 of 2014 concerning Hajj Financial Management. Furthermore, this benefit program is regulated in $\mathrm{BPKH}$ Regulation No 7 of 2018 concerning Priority Determination of Beneficial Activities and Use of the Value of the Benefits of the People's Endowment Fund. The benefits program is run through the use of the DAU, the amount of the benefit value of the DAU that can be used for activities for the benefit of Muslims,

\footnotetext{
38 Muhammad Asfiroyan, "Optimalisasi Dana Haji Pembangunan Sektor Riil Melalui Skema Project Based sukuk," Politeknik Keuangan...,p. 6. See: Law No. 19 of 2018 concerning SBSN and Government Regulation No. 56 of 2011 concerning Project Financing through SBSN.
} 
which is at most the same as the value of the DAU benefit in the previous year. ${ }^{39}$

Priorities in the benefits program include services for the pilgrimage, education, da'wah, health, socio-religion, the economy of the people, and the construction of worship facilities and infrastructure. Determination in the benefits program, each agency or organization has the right to apply for benefit programs, including internal $\mathrm{BPKH}$. This benefit program submission is submitted through a proposal which will then be assessed for feasibility by BPKH.

In providing the value of benefits to the beneficiaries who have been approved, the value of the benefits can be given directly or indirectly, namely through benefit partners. In contrast, the form of the value of the benefits provided is consumptive or consumable; this is based on article $23 \mathrm{PBPKH}$, the value of the help given to Direct beneficiaries can be delivered in the form of money, goods, and or services in the form of gifts or grants, assistance, and waqf.

DAU is a separate source of hajj financial revenue from BPIH (Hajj Organizing Fees). As stated in the regulations, DAU is intended for the benefit of Muslims. The DAU is enough to be in the public spotlight in the management of Hajj finances, how not, the considerable amount has proven to attract the attention of several stakeholders, the two previous Ministers of Religion, Said Agil and Suryadharma Ali, are vivid in memory, becoming a dark record in the management of Hajj finances. The Ministry of Religion, which was very much in charge of the financial management of the Hajj, had become a byword in the community. $\mathrm{BPKH}$ is present in the mandate of Law No.

39 This is regulated in BPKH Regulation No. 7 of 2018 in Article 3.
34 of 2014, which is expected to close the dark door of DAU financial management.

Last April 2019, the hammer rattled Law No. 8 of 2019 regarding the organization of the Hajj as an amendment to Law No. 13 of 2008 concerning the implementation of the Hajj. Its ratification did not attract public attention; even the bill was never discussed, not as exciting as the K.P.K. bill, even though the Law will reflect the implementation of the Hajj in the future.

It is enough to attract the attention of researchers that there is something slightly different in this Law on other Hajj regulations. The general provisions of each Hajj regulation define the DAU. This Law also does not discuss the financial management of the Hajj. This concludes that the government's efforts to focus the Act on the management and implementation of Hajj separately. So that the basis for the financial management of Hajj is based on Law No. 34 of 2014, and the organization of the Hajj pilgrimage is based on Law No. 8 of 2019.

Despite the government's efforts to provide clarity and a positive impact on the financial management of Hajj, it has resulted in disharmony and inconsistency in the direction of the Ummah's endowment fund. This can be seen in Article 129 of Law No. 8 of 2019, which states that the Indonesian Hajj Supervisory Commission and the People's Endowment Fund Management Agency are declared disbanded. The minister carries out their functions and duties. This is not in line with Law No. 34 of 2014, which gives BPKH the authority to manage Hajj Finance, including the People's Endowment Fund. This disharmony shows dualism of charge in the People's Endowment Fund management. ${ }^{40}$

40 Muhammad Aziz Zakiruddin, "Problematika 
Although in practice, the DAU is in the direction of BPKH. However, the duality of authority shows how weak the regulations are in managing the financial management of the Hajj so that legally the financial management of the Hajj cannot run appropriately through overlapping regulations and does not show legal certainty and consistency between other restrictions. ${ }^{41}$

It should also be highlighted in the use of the People's Endowment Fund, which is consumptive or used up. Efficiency and sustainable development are essential principles in providing value for benefits and how to minimize wasteful benefit activities to build good governance based on efficiency.

Efficiency and sustainability are expected to be the principles genuinely built in the management of Hajj finances, especially in the DAU. Pancasila, as a staats fundamental norm, provides fundamental values, which should also be the ideology underlying the financial management of Hajj because Pancasila is also an ideology and identity in economic development. Developments and innovations in the direction of Hajj have touched the realm of the economy and even nationally so that the DAU's ideals for the benefit should not be limited only to the scope of Muslims but also provide the nation's economic benefit at large. An idea in the minds of researchers to build an

Regulasi Pengelolaan Dana Abadi Umat: Disharmonisasi Kelembagaan dan Legal Standing, Media Syariah, Wahana Kajian Hukum Islam dan Pranata Sosial, Vol. 23, No.1, Juni 2021, p. 51

41 Lon F. Fuller dala mteorinya Morality of law, mengatakan They should be a congruence between the laws as announced and their actual administration, the law must have consistency between the rules as announced and the implementation in fact, the law is inconsistent with other rules is one of the eight causes of failure of legislation.See: Ahmad Redi, Hukum Pembentuk Peraturan Perundangundangan (Jakarta: Sinar Grafika, 2018), p.44. efficient and sustainable DAU, Micro, Small, and Medium Enterprises (MSMEs) can be the choice and target of $\mathrm{BPKH}$ in helping the economy of the middle to lower people.

\section{Conclusion}

Every regulation, Law, or other regulation aims to realize good Hajj financial management. Regulations provide room for movement and limit the space for exercise, and regulation can also be a reproach that can worsen the condition of Hajj financial management. How the government as the holder of power can provide legal certainty that can form a government in this case, in particular, $\mathrm{BPKH}$ can carry out its duties professionally, which can uphold the values of transparency, justice divinity, and benefit.

The dynamics that occur in the regulation of Hajj financial management are still not optimal in fulfilling Good Governance efforts. This can be seen from the overlapping and disharmony between the Hajj Financial Management Act and the Hajj Organizing Law. So, in an attempt to build Hajj financial management based on good governance, it is necessary to improve from the regulatory aspect and close various defects that can damage the implementation of Hajj financial management. How regulations can support the ideals of Hajj financial management as contained in the mandate of the Law to be able to provide value for benefits can be appropriately implemented. The value of the benefits itself is felt not to focus on the use of Muslims alone but can give valuable benefits to the national economy as the ideals of economic development in Pancasila. 


\section{References}

Anggara, Sahya, Ilmu Administrasi Negara Kajian Konsep, Teori dan Fakta dalam Upaya menciptakan Good Governance, Bandung: CV Pustaka Setia, 2012.

Asfiroyan, Muhammad, "Optimalisasi Dana Haji Pembangunan Sektor Riil Melalui Skema Project Based sukuk," Politeknik Keuangan Negara, STAN.

Aziz Zakiruddin, Muhammad, "Problematika Regulasi Pengelolaan Dana Abadi Umat: Disharmonisasi Kelembagaan dan Legal Standing, Media Syariah: Wahana Kajian Hukum Islam dan Pranata Sosial, Vol. 23, No.1, Juni 2021

"BPKH: Tidak sepeserpun dana haji untu kinfrastruktur," https://ekonomi.kompas. $\mathrm{com} / \mathrm{read} / 2019 / 01 / 24 / 142008126 / \mathrm{bpkh}$ tidak-ada-satu-rupiah-dana-haji-untukinfrastruktur. Accessed on 9 September 2021.

Badan Pengelolahan Keuangan Haji, "Pengelolahan Dana Haji dan Rencana Strategis BPKH 2018-2022” http://BPKH.co.id, Jakarta (Desember 2017).

"Dana Haji Indonesia mencapai Rp 105 trilliun," https://bandung.kompas.com/read/ 2018/05/21/13033161/dana-haji-di-Acapai-rp-105-triliun.\%20\%20.Accessed on 9 September 2021.

Fauzan,Ahmad, "Pelayaran Angkutan Jamaah Haji di Hindia Belanda 1911-1930)" AlTuras, Vol. XXII, No. 1, Januari 2016.

Harahap, Sumuran dan Mursidi Mr, Lintasan Sejarah Perjalanan Jemaah Haji Indonesia, Jakarta: Insan Cemerlang, TT.

"Jokowi Ingin Dana Haji diinvestasikan Untuk Infrastruktur," https://nasional.kompas. $\mathrm{com} / \mathrm{read} / 2017 / 07 / 26 / 12145401 /$ jokowiingin-dana-haji-diinvestasikan-untukinfrastruktur? page=all. Accessed on 9 September 2021.

Jumali, Endang, "Management Of Hajj Funds In Indonesia," Journal of Legal, Sultan
Zainal Abidin University, Vol. 21, No, 3, Malaysia 2018.

Karianga, Hendra, Politik Hukum dalam Pengelolahan Keuangan Daerah, Jakarta: Kencana, 2013.

Komisi VIII DPR RI, "Naskah Akademis Rancangan Undang-Undang tentang Penyelenggaraan Ibadah Haji dan Umrah, (April 2016).

Majid, M. Dien, Berhaji di Masa Kolonial, Jakarta: CV Sejahtera, 2008.

Nazri, Riko, "Bank Haji Indonesia: Optimalisasi Pengelolaan Dana Haji Untuk Kesejahteraan Jemaah Haji Indonesia (Sebuahgagasan)," Jurnal Khazanah I, FIAI Univesitas Islam Indonesia, Vol. 6, No. 1. Juni 2013.

Nizam, Achmad dan Hanan, Alatief, Manajemen Haji: Studi Kasus dan Telaah Implementasi Knowledge Worker, Jakarta: Zikrul Hakim, 2003.

Noer, Deliar, Administrasi Islam di Indonesia, Jakarta: CV Rajawali, 1983.

NurIchwan, Moch,"Governing Hajj: Politics of Islamic Pilgrimage Services in Indonesia Prior to Reformasi Era," Al-Jami'ah, Vol. 46, No. 1, (2008).

Nuri, Muhammad, "Pragmatisme Penyelenggaraan Ibadah Haji di Indonesia," Jurnal Sosial dan Budaya Syar-I UIN Jakarta, Vol. 1, No.1, Juni 2014.

Redi, Ahmad, Hukum Pembentuk Peraturan Perundang-undangan, Jakarta: Sinar Grafika, 2018.

Subianto, Ahmad, Menata Kembali Manajemen Haji Indonesia (Jakarta: Yakamus dan Gibon Books, 2016), Cet ke-1

Sudding, Sarifuddin, Perselingkuhan Hukumdan Politik dalam Negara Demokrasi, Yogyakarta: Rangkanf Education, 2014.

Taufiq Possumah, Bayu,"Hajj Fund for Infrastructure Development: a Dilemma for Indonesian Muslim," Islamic Finance news, Univestiti Malaysia Terengganu, Malaysia 16 Agustus 2017. 
Vredenbregt, Jacob, "The Haddj: Some of its Features and Function in Indonesia, Brijdragen tot de taal, Brill, 1962.

Widodo, Joko, Good Governance: Telaah dari Dimensi Akuntabilitasm Kontrol Birokrasi Pada Era Desentralis dan Otonomi Daerah. Surabaya: InsanCendikia, 2001.
Yaqub, Ali Mustafa, Haji Pengabdi Setan, Jakarta: PT PustakaFirdaus, 2015.

Zubaedi, "Analisis Problematik Manajemen Pelaksanaan Haji di Indonesia," Jurnal Manhaj I, Fakultas Tarbiyah dan Tadris IAIN Bengkulu, Vol. 4, No 3, September 2016. 